\section{Merck Encycles through Canada}

\section{By Michael J. Haas, Associate Editor}

The first disclosed grant under Merck \& Co. Inc.'s Canadian translational initiative will bolster the ability of macrocycle-based Encycle Therapeutics Inc. to conduct lead optimization of its integrin $\alpha_{4} \beta_{7}$ inhibitors for inflammatory bowel disease.

Last year, Merck launched the initiative with a C $\$ 4$ million ( $\$ 3.5$ million) fund to support—and give a first look at—research from early stage companies and academic institutes across the country.

The announced deal will help finance a joint team from Encycle and the Institute for Research in Immunology and Cancer (IRIC) to perform medicinal chemistry and preclinical efficacy studies. IRIC is a translational unit housed at the University of Montreal.

Encycle is a spinout from the University of Toronto founded in 2012 to solve the primary challenges of macrocycle drugs-poor cell penetration and low oral availability. ${ }^{1,2}$

According to Parimal Nathwani, the company was selected by MaRS Innovation and IRICoR (Institute for Research in Immunology and Cancer-Commercialization of Research), two of the three agencies originally tasked with disbursement and management of the Merck fund, because it was a good match with IRIC's competencies. The third agency, The Centre for Drug Research and Development, is not involved in this deal. IRICoR is the commercialization arm of IRIC.

"Encycle has a good chemistry platform and nice early discovery work on its integrin $\alpha_{4} \beta_{7}$ inhibitor program, which is now at the point where it needs to move through lead optimization," said Nathwani. "IRIC scientists have strong expertise in medicinal chemistry and have worked with industry on optimization, pharmacokinetics, toxicity and other preclinical studies, so they can provide Encycle with pharma-grade optimization."

Nathwani is VP of life sciences at MaRS Innovation, a translational center that commercializes discoveries from 16 academic institutions and hospitals in Ontario, including the University of Toronto.

Encycle president and CEO Jeffrey Coull told SciBX, "We initiated lead optimization of our integrin $\alpha_{4} \beta_{7}$ inhibitors a few months ago and so far have identified some compounds with good potency and membrane permeability to demonstrate that our program has strong potential."

He said that the funds from Merck - combined with an equal financial contribution from Encycle-will allow his company to create "an integrated optimization team" that will conduct additional medicinal chemistry and in vivo studies.

He added, "For us, it's all about bandwidth. IRIC adds to the expertise we already have in-house and will accelerate our efforts and get us across the finish line with a lead development candidate."

MaRS Innovation and IRICoR will manage the Merck funds for the joint Encycle-IRIC research team. Nathwani declined to disclose how much money the Encycle project will receive but said the deal gives IRICoR an equity stake in Encycle and increases MaRS Innovation's existing stake.

\section{Macrocircular arguments}

Encycle's macrocycle platform includes three features not found together in other macrocycle platforms: a lack of sulfur to enhance metabolic stability; inclusion of several intramolecular hydrogen bonds that alter the molecules' folding and increase their ability to permeate cell membranes; and an upper size limit of three to five amino acids, which gives the molecules better oral availability than larger rings typically achieve. ${ }^{3}$

According to Coull, this combination of features gives the moleculeswhich Encycle has dubbed 'nacellins', a reference to their boat (nacelle)-like conformation-longer in vivo half-lives than sulfur-containing macrocycles and greater cell penetration than macrocycles that have fewer intramolecular hydrogen-bonding motifs.

The most advanced macrocycle in development is Polyphor Ltd.'s POL6326, a conformationally constrained peptide that antagonizes CXC chemokine receptor 4 (CXCR4; NPY3R). The compound is in Phase II testing to treat multiple myeloma (MM) using autologous transplantation of hematopoietic stem cells. At least seven other companies have macrocycles or conformationally restrained peptides or peptidomimetics in development to treat a range of diseases.

Encycle's lead nacellin program inhibits integrin $\alpha_{4} \beta_{7}$, a protein expressed by lymphocytes that binds mucosal vascular addressin cell adhesion molecule 1 (MAdCAM-1) on endothelial cells. The interaction drives proinflammatory cells to leave the circulation for the gut, which contributes to the chronic inflammation in IBD.

This fall, Encycle's collaborators at Roswell Park Cancer Institute completed studies of one of the anti-integrin $\alpha_{4} \beta_{7}$ nacellins, ET-377, in a mouse model of colitis that tested the ability of the compound to block movement of lymphocytes out of the plasma.

"We got some very interesting data from the study and saw good efficacy for the compound" in this model, Coull told SciBX. He said that ET-377 produced results in the model comparable to those for two antibodies-an anti-mouse integrin $\alpha_{4} \beta_{7} \mathrm{mAb}$ and an anti-mouse Madcam-1 mAb-when it was run in a head-to-head comparison.

In its second nacellin program, Encycle is using its macrocycle technology to tackle hard-to-reach proteins involved in ubiquitination.

"Pharma has been going after E3 ubiquitin ligases for years without success," Coull said, "but it's been a tough nut to crack because the protein- 


\section{ANALYSIS}

\section{TRANSLATIONAL NOTES}

protein interactions involved are intracellular. We thought we could make a nacellin large enough to interrupt SMURF's interactions with other proteins but small enough to get inside the cell."

SMAD specific E3 ubiquitin protein ligase 1 (SMURF1) and SMURF2-targets of Encycle's program-are important regulators in the focal adhesion dynamics in cancer and fibrosis.

Coull said that Encycle has made active cell-permeable inhibitors of SMURF1 and SMURF2. Because good membrane permeability is an important advantage for nacellins, Encycle collaborated with a biochemist from the University of Toronto to develop an algorithm for predicting membrane permeability. Coull said that the algorithm uses seven different physical properties of nacellins.

"The algorithm gives us a global understanding of how nacellins get through cell membranes and bind their targets, and we are actively employing it in lead optimization for both of our programs," he told SciBX.

Encycle has also completed a project funded by CQDM to generate a target-agnostic library of 1,500 nacellins. Each of the four pharma partners involved in the project-AstraZeneca plc, GlaxoSmithKline plc, Merck and Pfizer Inc. - has the right to screen the library against two targets of its choice. Coull expects the screenings to begin in about a month.

CQDM, formerly the Quebec Consortium for Drug Discovery, receives funding from the federal and provincial governments, eight pharma sponsors and other partners to support the development of precompetitive research tools and technologies.

Encycle has raised C \$2.5 million (\$2.2 million) in seed funding, most of which comes from MaRS Innovation. The company is also raising C\$10-15 million (\$8.8-13.1 million) in a series A round to fund the integrin $\alpha_{4} \beta_{7}$ program through Phase II trials. Encycle expects to close the round in $1 \mathrm{H} 15$.
Nathwani said that MaRS Innovation is putting together two other medicinal chemistry programs with IRICoR that would be funded by the Merck grant and expects to announce those programs in 1Q15.

Steven Klein, IRICoR's VP of business development, told SciBX that funds from the Merck initiative have also gone to two other projects that are jointly managed by IRICoR and the Centre for Drug Research and Development, but the details of those projects are undisclosed.

Haas, M.J. SciBX 7(46); doi:10.1038/scibx.2014.1338

Published online Dec. 4, 2014

\section{REFERENCES}

1. Kotz, J. SciBX 5(45); doi:10.1038/scibx.2012.1176

2. Cain, C. BioCentury 20(38) A7-A13 (2012); Sept. 17, 2012

3. Haas, M.J. BioCentury 13; Aug. 4, 2014

\section{COMPANIES AND INSTITUTIONS MENTIONED}

AstraZeneca plc (LSE:AZN; NYSE:AZN), London, U.K. The Centre for Drug Research and Development, Vancouver, British Columbia, Canada

CQDM, Montreal, Quebec, Canada

Encycle Therapeutics Inc., Toronto, Ontario, Canada

GlaxoSmithKline plc (LSE:GSK; NYSE:GSK), London, U.K. Institute for Research in Immunology and Cancer, Montreal, Quebec, Canada

Institute for Research in Immunology and CancerCommercialization of Research, Montreal, Quebec, Canada

MaRS Innovation, Toronto, Ontario, Canada

Merck \& Co. Inc. (NYSE:MRK), Whitehouse Station, N.J.

Pfizer Inc. (NYSE:PFE), New York, N.Y.

Polyphor Ltd., Allschwil, Switzerland

Roswell Park Cancer Institute, Buffalo, N.Y.

University of Montreal, Montreal, Quebec, Canada

University of Toronto, Toronto, Ontario, Canada 